\title{
Zirconium Plate Measuring Instrument (ZPMI) Design Report
}

\author{
K. Davies \\ J. H. Jackson
}

October 2013

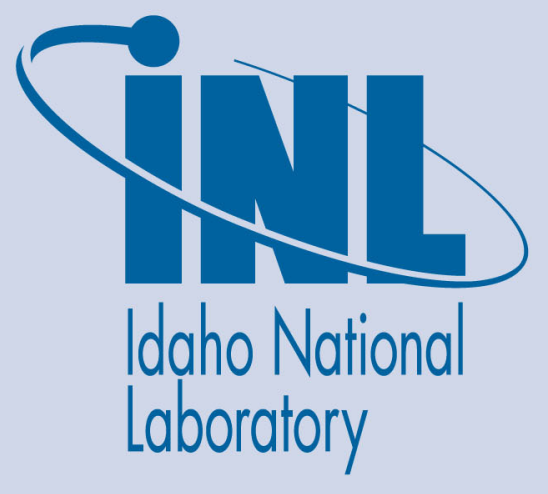

The INL is a U.S. Department of Energy National Laboratory operated by Battelle Energy Alliance 


\section{DISCLAIMER}

This information was prepared as an account of work sponsored by an agency of the U.S. Government. Neither the U.S. Government nor any agency thereof, nor any of their employees, makes any warranty, expressed or implied, or assumes any legal liability or responsibility for the accuracy, completeness, or usefulness, of any information, apparatus, product, or process disclosed, or represents that its use would not infringe privately owned rights. References herein to any specific commercial product, process, or service by trade name, trade mark, manufacturer, or otherwise, does not necessarily constitute or imply its endorsement, recommendation, or favoring by the U.S. Government or any agency thereof. The views and opinions of authors expressed herein do not necessarily state or reflect those of the U.S. Government or any agency thereof. 


\section{Zirconium Plate Measuring Instrument (ZPMI) Design Report}

K. Davies

J. H. Jackson

October 2013

Idaho National Laboratory

Idaho Falls, Idaho 83415

http://www.inl.gov

Prepared for the

U.S. Department of Energy

Office of Nuclear Energy

Under DOE Idaho Operations Office

Contract DE-AC07-05ID14517 


\begin{abstract}
This report describes the design of a device intended to measure radiation-induced strain in zirconium plate specimens as a function of neutron fluence.
\end{abstract}




\section{CONTENTS}

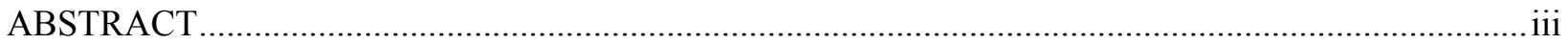

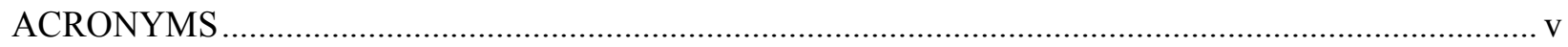

Background, Conditions, and Design Considerations: ................................................................ 1

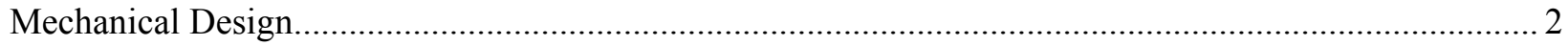

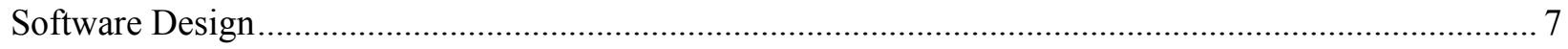

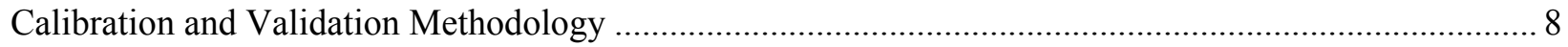

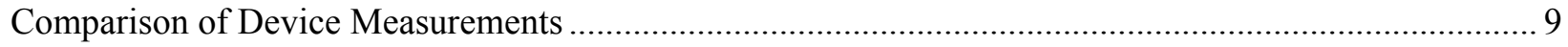

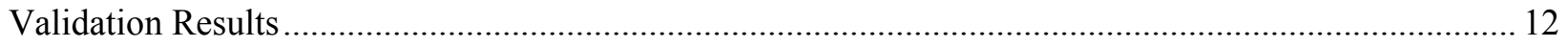

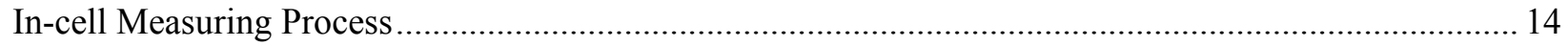

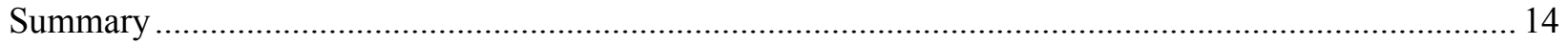

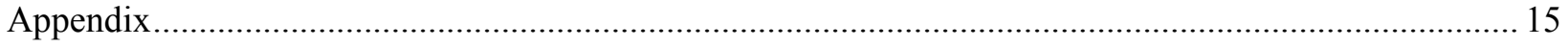

Reference 1: Newmark Linear Positioner Specifications......................................................... 15

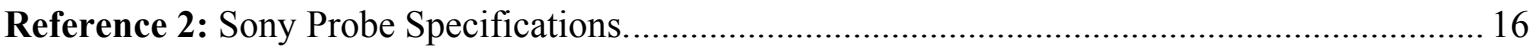

Reference 3: Precision Gauge Block Validation of Probes........................................................... 17

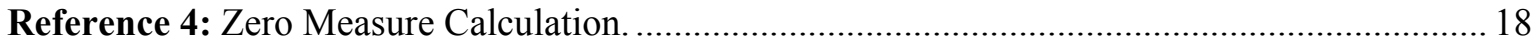

Reference 5: Validation of Second Device to First Device Measurements.................................... 19

Reference 6: Validation of In-cell to Out-of-Cell Measurements. ............................................... 20 


\section{FIGURES}

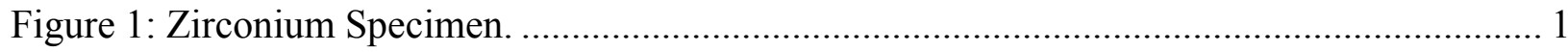

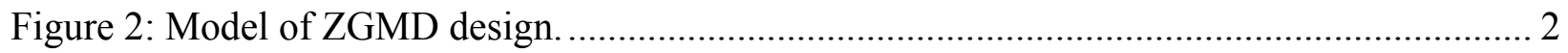

Figure 3: Recommended Mounting Dimensions and Tolerances............................................ 3

Figure 4: Completed In-cell Equipment. .............................................................................. 4

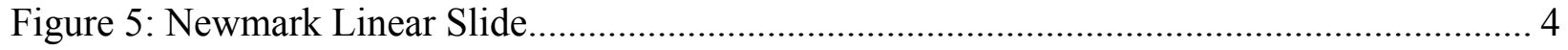

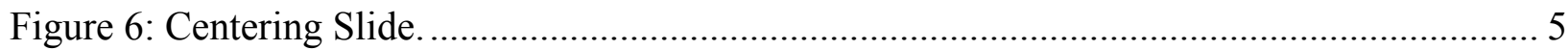

Figure 7: Computer Graphical Model............................................................................ 5

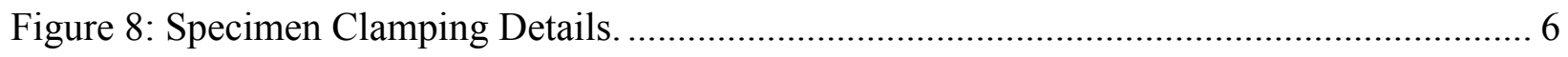

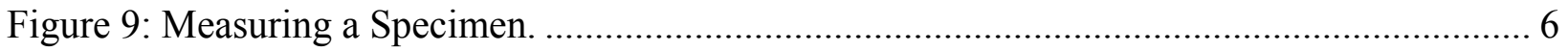

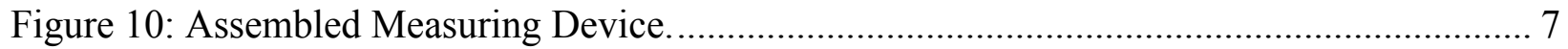

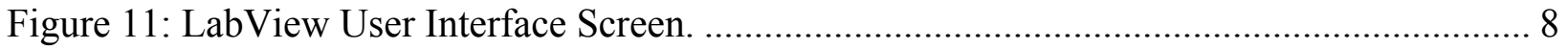

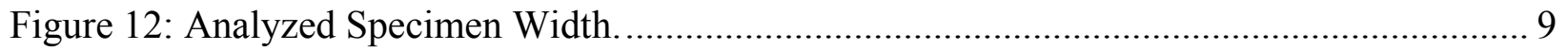

Figure 13: A Typical and Unique Measurement Profile...................................................... 10

Figure 14: Reference Specimen Profile Comparisons..................................................... 11

Figure 15: Probe Elevation Differences (not to scale).......................................................... 12

Figure 16: In-cell Verification with Reference Specimens................................................. 13

\section{ACRONYMS}

CMM - Coordinate Measuring Machine

ECAR - Engineering Calculation and Analysis Report

EPRI - Electric Power Research Institute

ID - Identification

INL - Idaho National Laboratory

LVDT - Linear Variable Differential Transformer

QA - Quality Assurance

ZGMD - Zirconium Growth Measuring Device

ZPMI - Zirconium Plate Measuring Instrument 


\section{Zirconium Plate Measuring Instrument (ZPMI) Design}

\section{Background, Conditions, and Design Considerations:}

The specimens to be measured by this device are a nominal size of $34.9 \mathrm{~mm} \times 6.5 \mathrm{~mm}$ x $0.8 \mathrm{~mm}$ $(1.375 " \times 0.255 " \times 0.031$ "). The $34.9 \mathrm{~mm}(1.375$ ") length was precisely measured prior to irradiation and will be measured a second time following exposure in order to quantify radiation induced strain as shown in Figure 1.

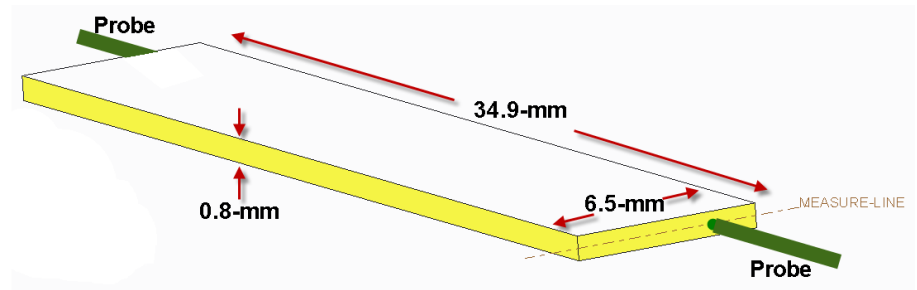

Figure 1: Zirconium Specimen.

The lowest level of radiation exposure is expected to produce dimensional growth of approximately of $10 \mu \mathrm{m}$ to $20 \mu \mathrm{m}$ ( 0.0004 " to 0.0008 "). A measurement error of less than $5 \mu \mathrm{m}$ is a primary design requirement, along with the ability to reliably and consistently measure the plate specimens using remote manipulators in a hot cell environment.

The ZPMI measuring system is required to precisely and repeatedly measure changes in the single-digit micrometer range. Early in the design process, it was suggested by a teaming partner of the customer (EPRI), that equipment designed to take point-measurements of length between two opposed balls or cone points would provide the most accurate and useful information as illustrated also in Figure 1. With this approach, successive point measures along a measured line across the ends of the specimen provide a near continuous profile of specimen length.

Two ZPMI measuring devices were built based on commercially available components. The first was used to prove the design and initially measure the specimens prior to irradiation. The second, though similar in design, was adapted for remote measuring in the hotcell after specimen irradiation and is based partially on an existing Russian Institute of Atomic Research (RIAR) design. See Figure 2 for a computer model overview of the basic design of the second device. The term ZPMI is used to describe both the first measuring device and generically the entire measuring system. The term ZGMD (Zirconium Growth Measurement Device) was coined to specifically refer to the second device. This design discussion generally uses ZPMI in the generic sense and names the individual measuring devices as the first, second, or ZGMD devices. 


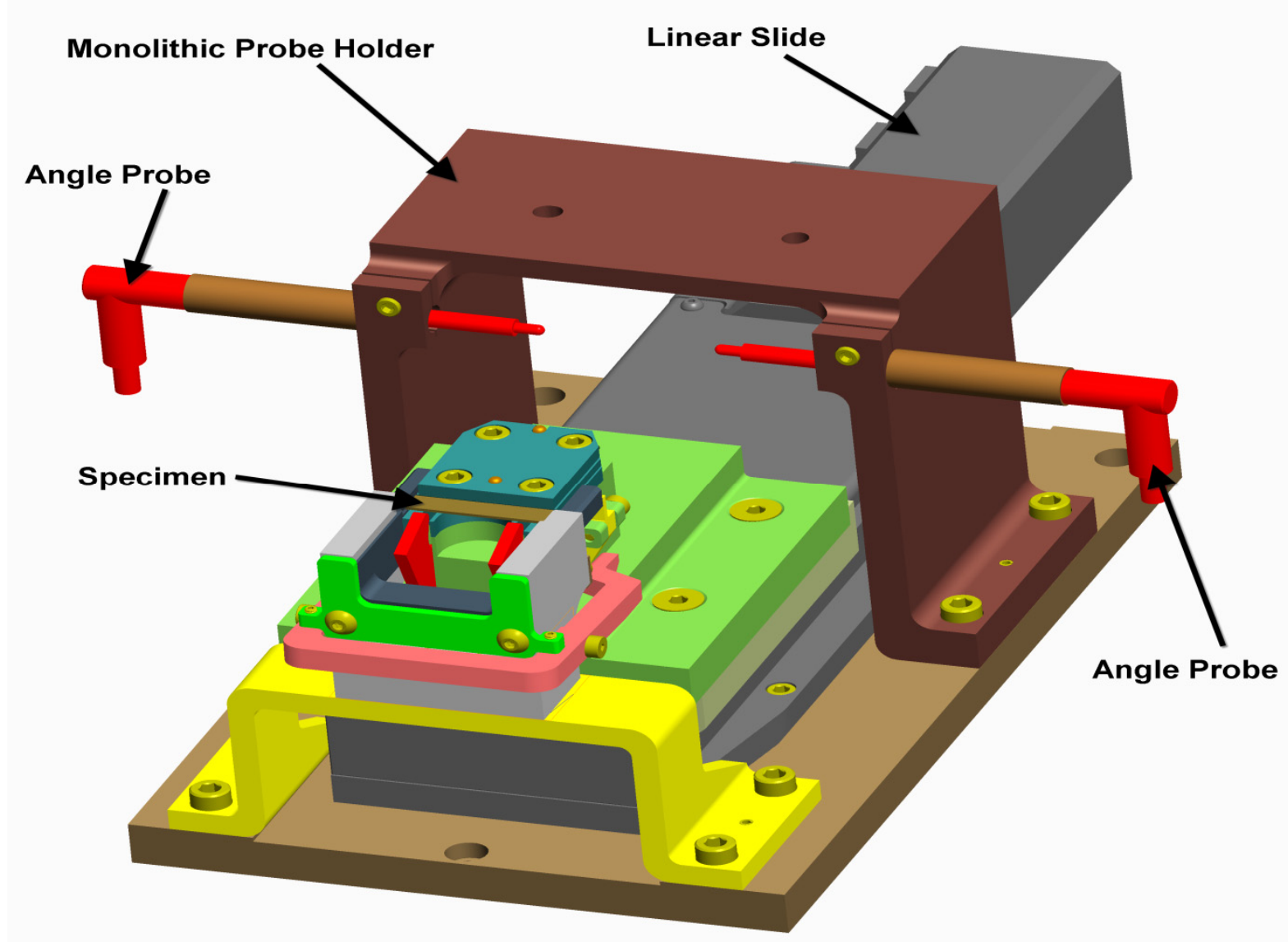

Figure 2: Model of ZGMD design.

An essential design concern was to provide a method of calibrating the equipment to a known and repeatable length standard. This is a main topic of this paper. Also, point measuring systems are sensitive to several factors and consistent successful measurements demand attention to these factors. The surface conditions of the measured specimens and the measuring device are important. These surfaces need to be clean, free of oil, dust, or other contaminants. Dust particles, body oils, or flakes of skin can all be too small to see with the unaided eye, yet add multiple micrometers to a measurement. Both a smooth surface finish on the measured surfaces and the squareness of the measured surfaces to the measuring probes are important to reduce data noise and measure differences resulting from the probes not tracking the same line with each measurement.

\section{Mechanical Design}

Both ZPMI measuring devices used high-resolution off-the-shelf commercial components that included two opposed Sony LVDTs (Linear Variable Differential Transformer) probes to measure specimen length and a Newmark linear slide to position the specimen between the probes for measuring. Manufacturer specifications for these components are attached in the appendix. Model DG810F Sony probes were used in the first measuring device. Model DG810BL probes were used in the second device. Measurement performance specifications for both probe models are the same. However, the BL probes are more compact with angle wiring 
and the bayonet mounting style provides easier control and accuracy in probe positioning. In addition, the probes were positioned in a probe holder machined from a single solid metal block for more rigidity in withstanding potential remote handling bumps and shocks. The first device used flange mount probes a bolted three-piece probe holder and. Figure 3 illustrates the recommended split mounting interface between probe and holder.

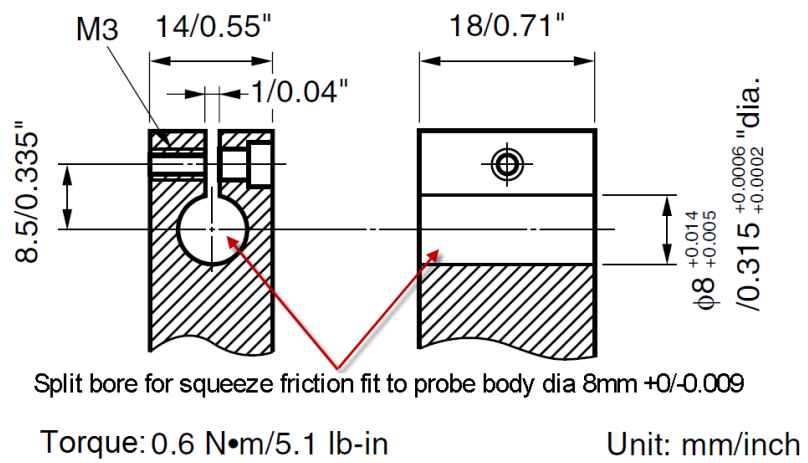

Figure 3: Recommended Mounting Dimensions and Tolerances.

Newmark series NLS4 linear slides were used in both measuring devices. The first device used a twelve-inch travel slide driven by a servo motor and resolver combination. The second device used a four-inch travel slide for a more compact design driven by a high resolution stepper motor. The stepper motor interfaced well with the Labview control software and provided more consistent and repeatable positioning across the specimens.

Figure 4 is a picture of the fabricated in-cell ZPMI equipment and identifies major components. The equipment is shown prior to being mounted on a larger base plate with handling fixtures and wiring junction boxes. The dollar bill taped to the table provides a sense of scale. The probes are held in a fixed position and the specimen to be measured is placed in a holder on the Newmark linear slide. The slide moves the specimen between the probes for measurement. The probes are mounted in a block machined from a single piece of aluminum for rigidity and accuracy of positioning the probes relative to the specimen. The target measuring line is across the center of the specimen's $0.8 \mathrm{~mm}$ thickness. 


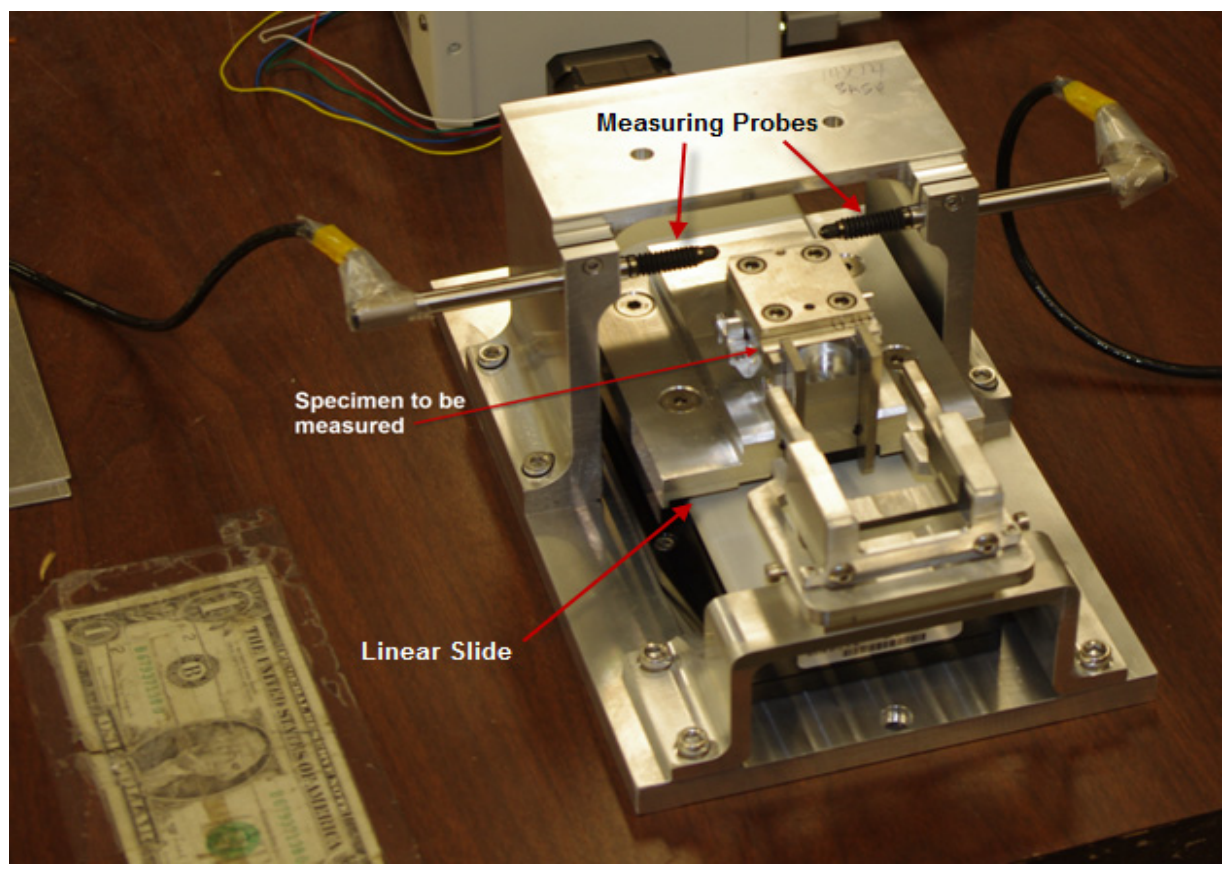

Figure 4: Completed In-cell Equipment.

Figure 5 shows more details of the Newmark slide and fabricated specimen holder. A specimen to be measured is placed in the fabricated holding area and centered by a centering slide (see Figure 6). The spring loaded clamps are then released to hold the specimen for the measuring sequence. The width of the specimen holder block has also been characterized and serves as a known distance to 'zero measure' the probes prior to measuring any specimen.

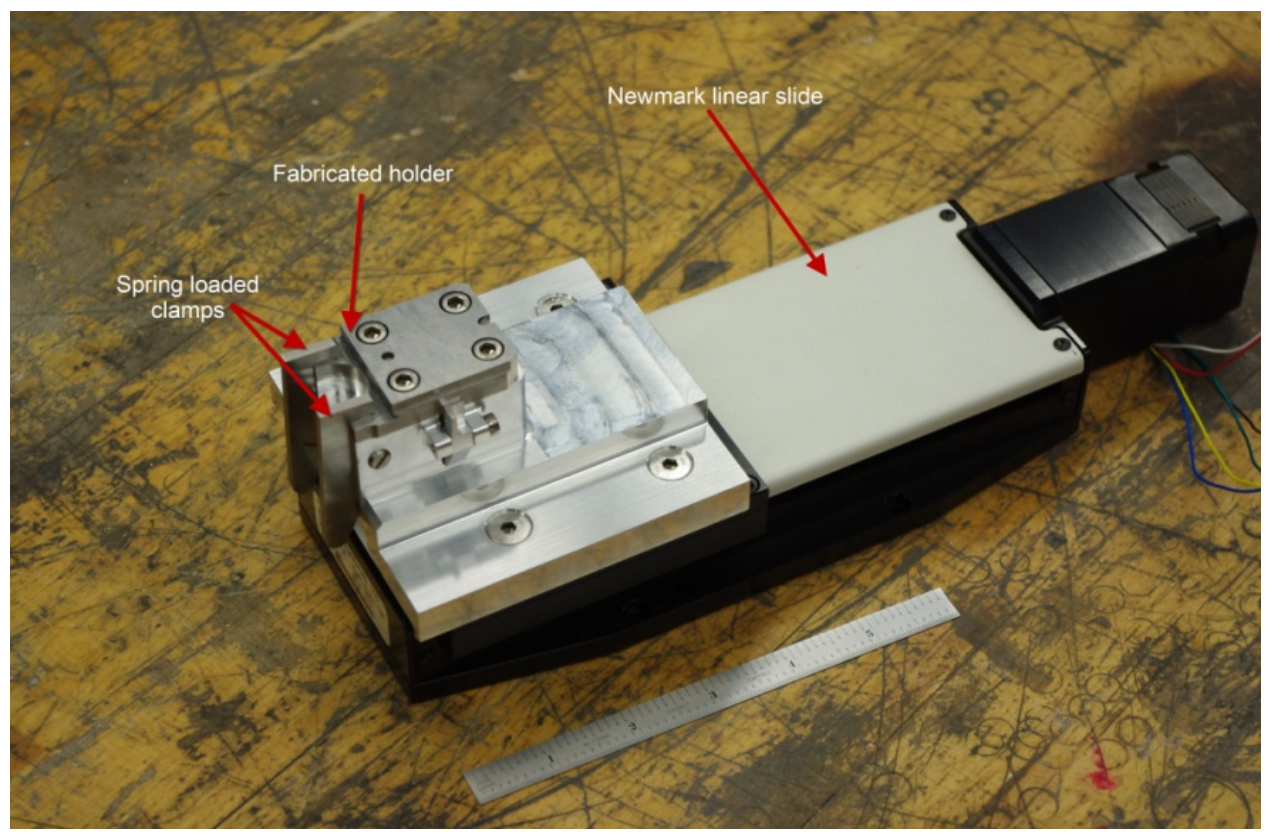

Figure 5: Newmark Linear Slide. 
Figure 6 shows another close-up with additional details of the centering slide. The centering slide is spring loaded. After placing a specimen in position, the slide is released and tapered sides center the specimen. The specimen is then ready to be clamped in position by the clamps for the measuring sequence.

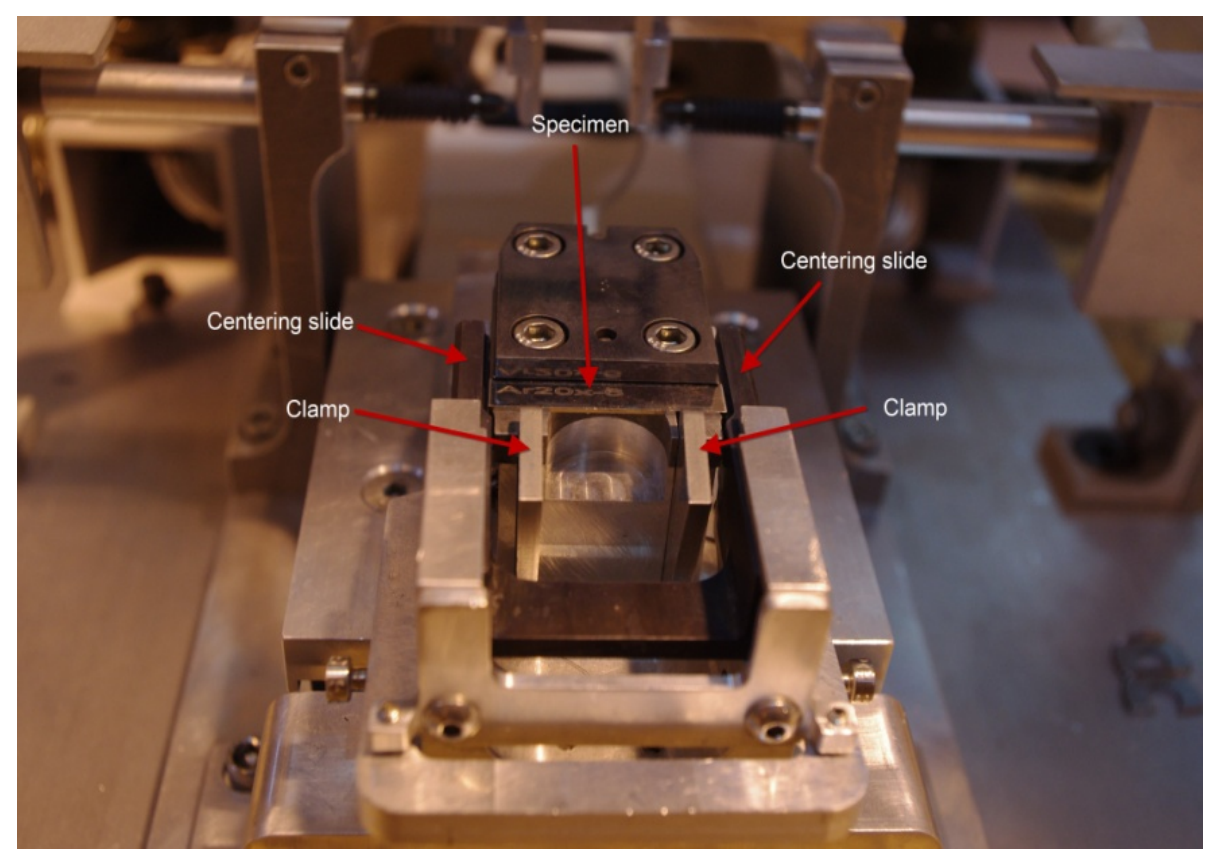

Figure 6: Centering Slide.

Computer generated graphical images of the design are shown in Figure 7 and Figure 8. They clearly show details of specimen clamping and relationship to probe travel and the zero location.

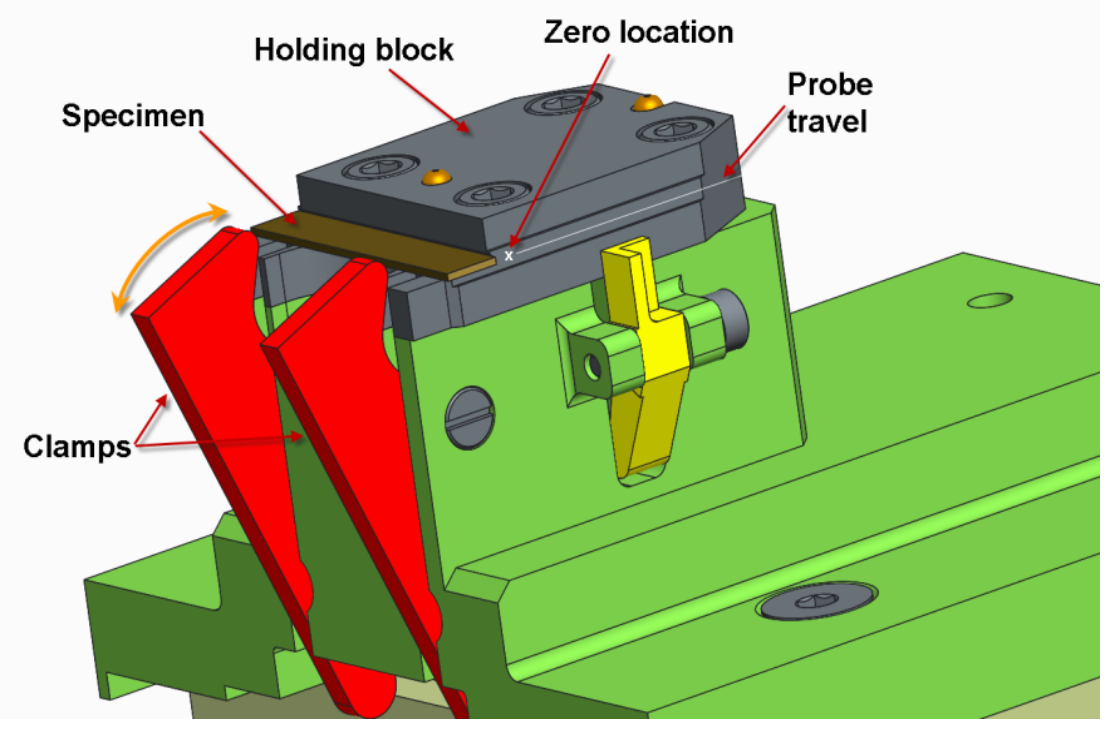

Figure 7: Computer Graphical Model. 
Figure 8 shows the clamps engaged and trapping the specimen under angled edges while the measurements are taken.

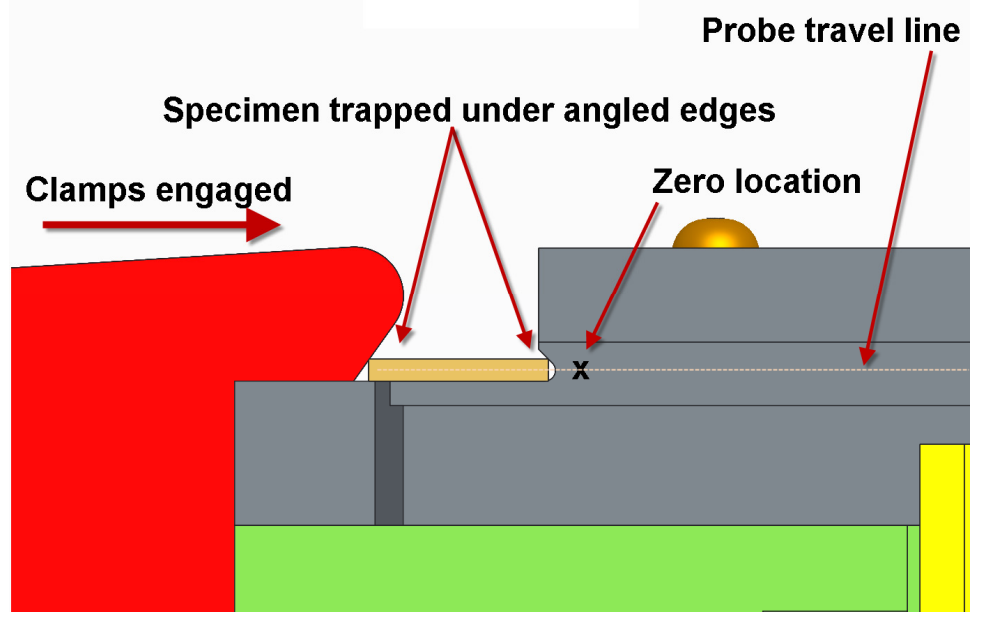

Figure 8: Specimen Clamping Details.

Figure 9 shows a measurement in progress. The slide moves the holder past the probes where the probes are 'zeroed' on the known width of the holder. The slide then moves the specimen past the probes and measurements are taken at typically $40-\mu \mathrm{m}$ intervals (approximately 160 measurements).

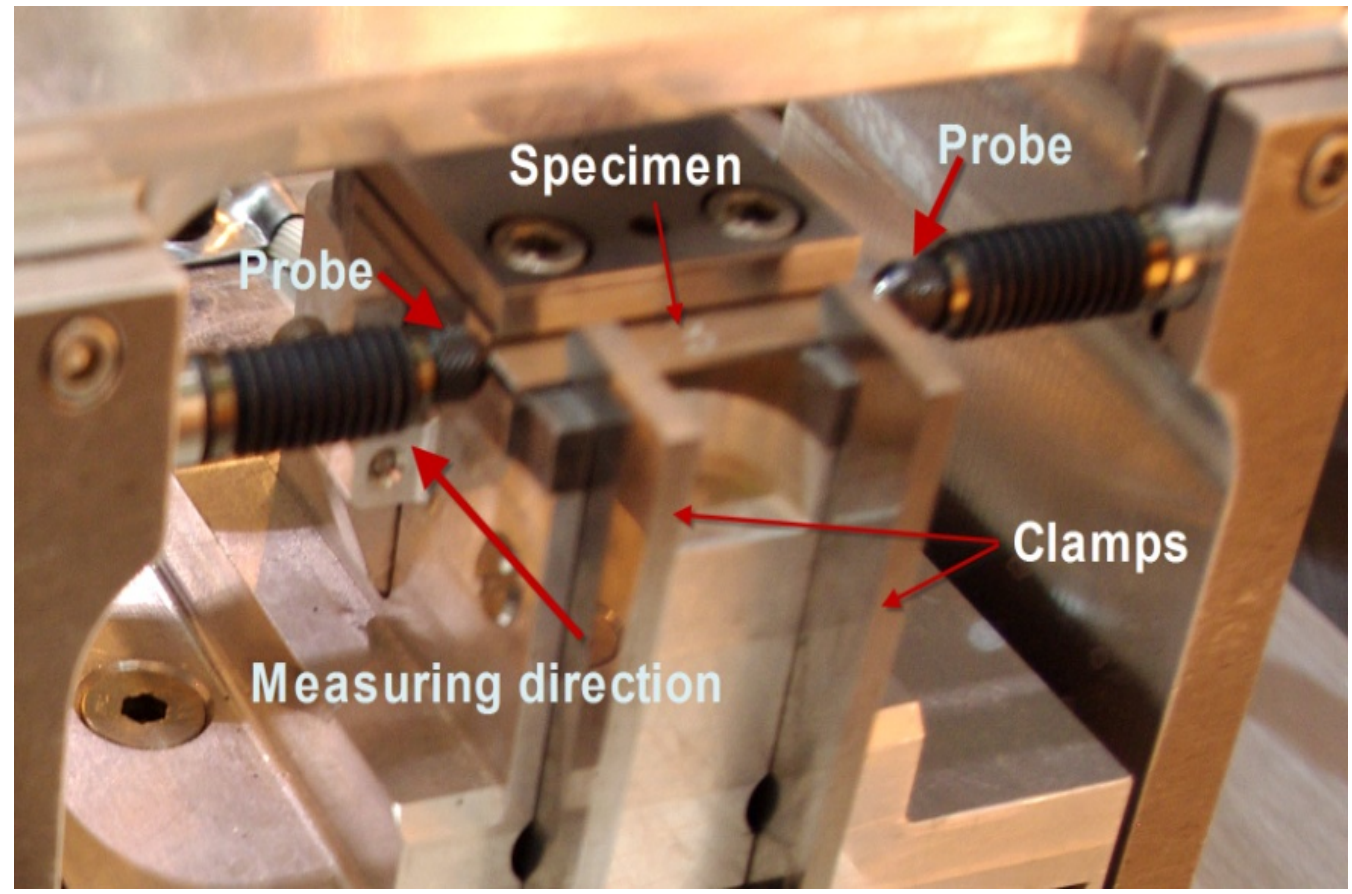

Figure 9: Measuring a Specimen. 
Figure 10 shows the complete assembly with handling fixtures and wiring ready to be sent incell. The tuner assembly is also shown. The tuner is used during initial setup to move the probes through a range of motion while the display is adjusted per manufacturer's instructions. The purpose is to optimize performance of the installed circuit configuration, maximizing gain and filtering out excessive noise.

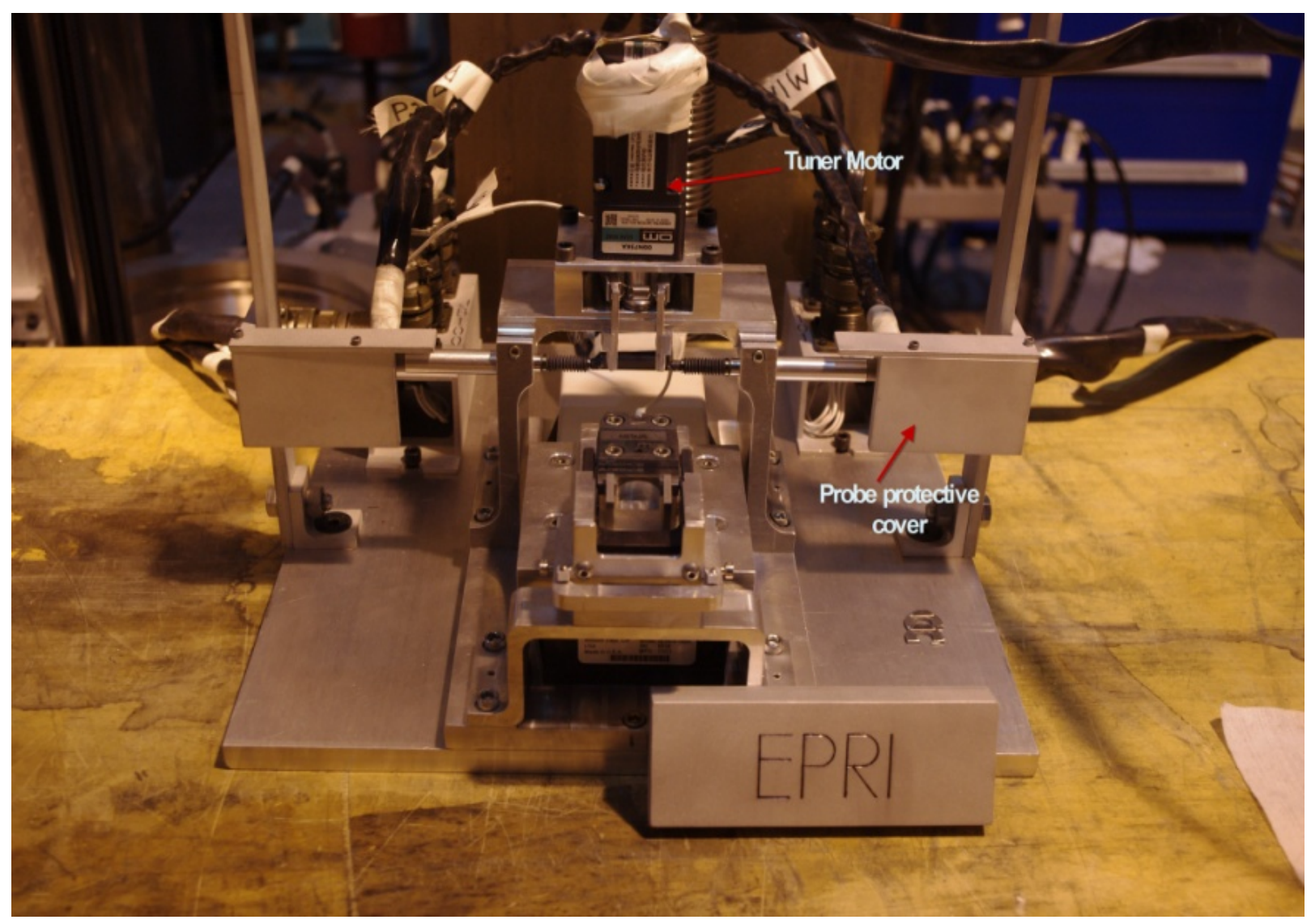

Figure 10: Assembled Measuring Device.

\section{Software Design}

National Instruments LabView software provides the user interface to communicate with the Newmark motor controller to position the slide, the probe display for probe measurement output, and an RTD transmitter for temperature output. During a measuring sequence the software initially queries the temperature and then issues move commands and queries for measurement data after each move. This data is written to text files for later retrieval. An on-screen dialog window is provided to give an operator a graphical view of the process and visual indication of proper operation. Figure 11 shows details of the user interface screen. 


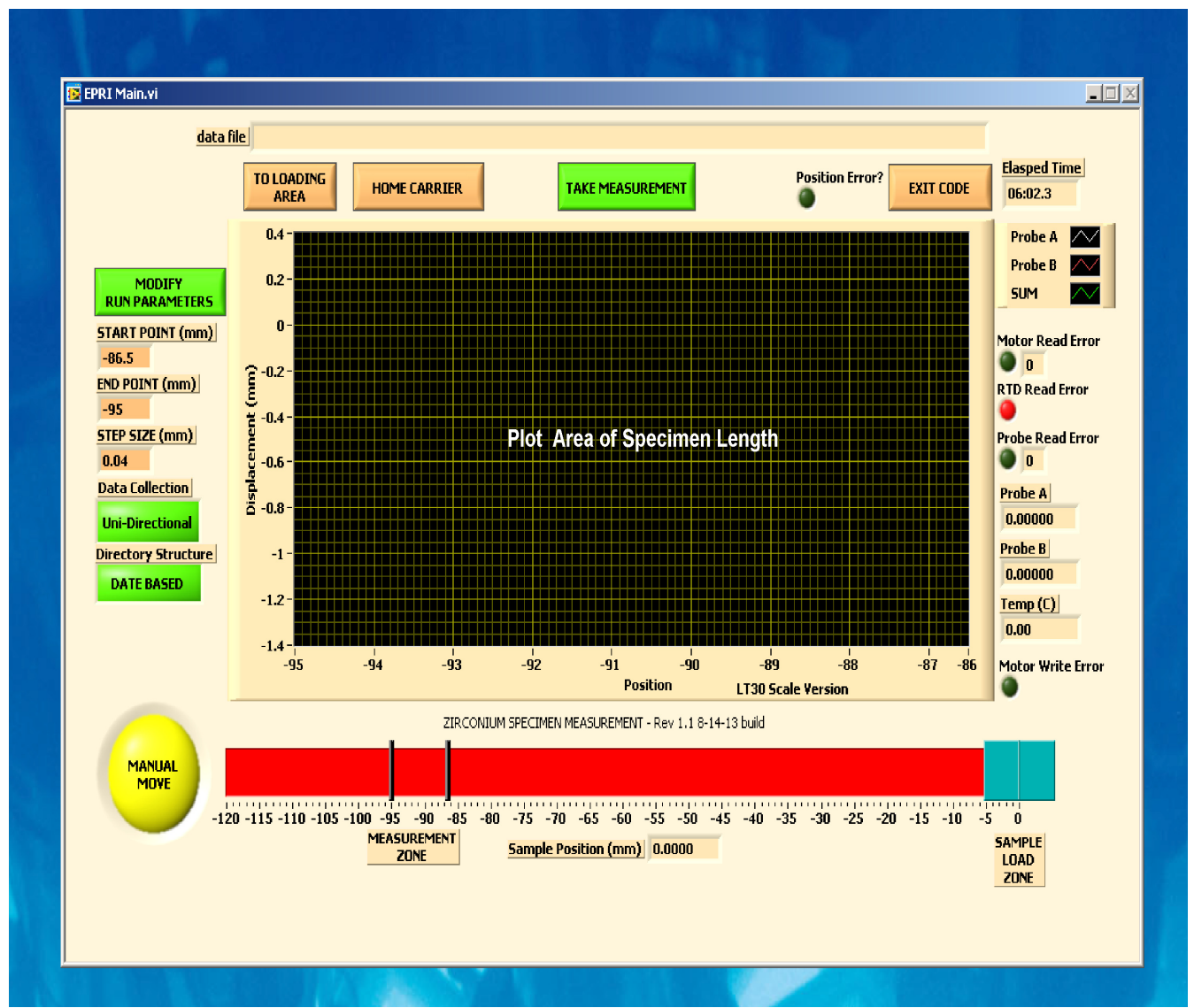

Figure 11: LabView User Interface Screen.

\section{Calibration and Validation Methodology}

The Sony LVDT probes measure length change and must start or end at a known distance to produce an absolute measure. The first measuring device was designed only for the initial hands-on measurements. The second device was designed for remote operation and for postirradiation measurements. Once the second device has been transferred in-cell, the ability to use standard QA precision gauge blocks or other typical QA controlled measuring devices is extremely difficult. It is essential not only to initially calibrate both devices and validate performance, but also validate the in-cell device for the life of the project which will be several years in duration.

The following method along with other independent measurement checks describes the initial calibration and validation. QA precision gauge blocks were used to establish the device measuring accuracy and precision and characterize the width at the zero location. The gauge blocks were placed in the same position as a specimen to duplicate the measuring process. A QA calibrated coordinate measuring machine $(\mathrm{CMM})$ was also used to measure and verify the zero width.

A second method established the process for continued validation after the second device was sent in-cell. A small set of four reference specimens was selected from all the specimens and held separately. These reference specimens were not irradiated, but kept for re-measure to 
validate the measuring device was consistently repeating the same measurements within the required uncertainty bounds. These reference specimens were also measured with a QA calibrated micrometer to verify the ZPMI measurements.

It should be noted that analysis of specimen measurements from both devices included only central measurements as illustrated in Figure 12. The original machining and polishing of the specimen ends and the differing centering processes used to position the specimens between the original measurement device and the new measurement device produced an unpredictable and changing profile on the specimen corners. Specifically, ZGMD measurements were taken at every $40-\mu \mathrm{m}$ or closer interval across the specimen ends. $40-\mu \mathrm{m}$ spacing results in some 160 data points. Data was normally taken in both directions providing verification and doubling of the data. If inspection showed no anomalies, one directional set of data points from the central width was used for analysis to avoid problems associated with specimen corners.

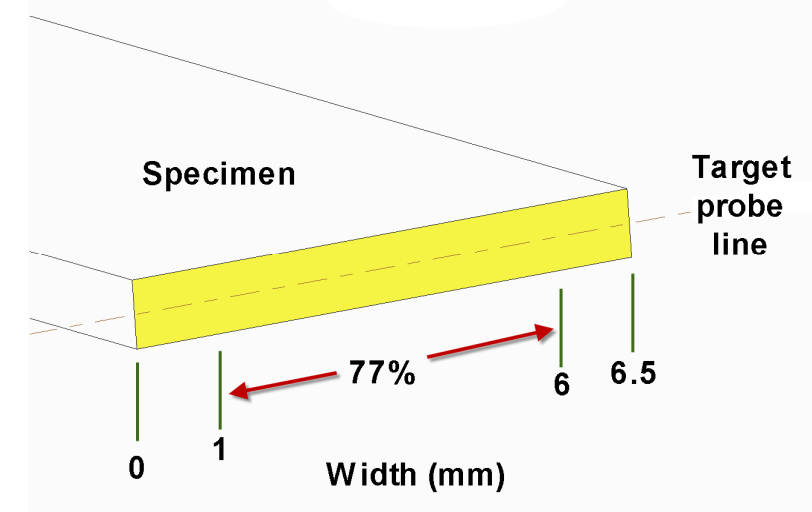

Figure 12: Analyzed Specimen Width.

\section{Comparison of Device Measurements}

The initial measurements of the reference specimens by both measuring devices provided direct comparison of results for specimen measurement. From the initial measurements with the first device, it was observed minor surface variation between specimens was sufficient to provide each specimen with a unique measurement profile as shown in Figure 13. For some specimens, this profile is unique enough to easily identify the specimen with no additional information. 


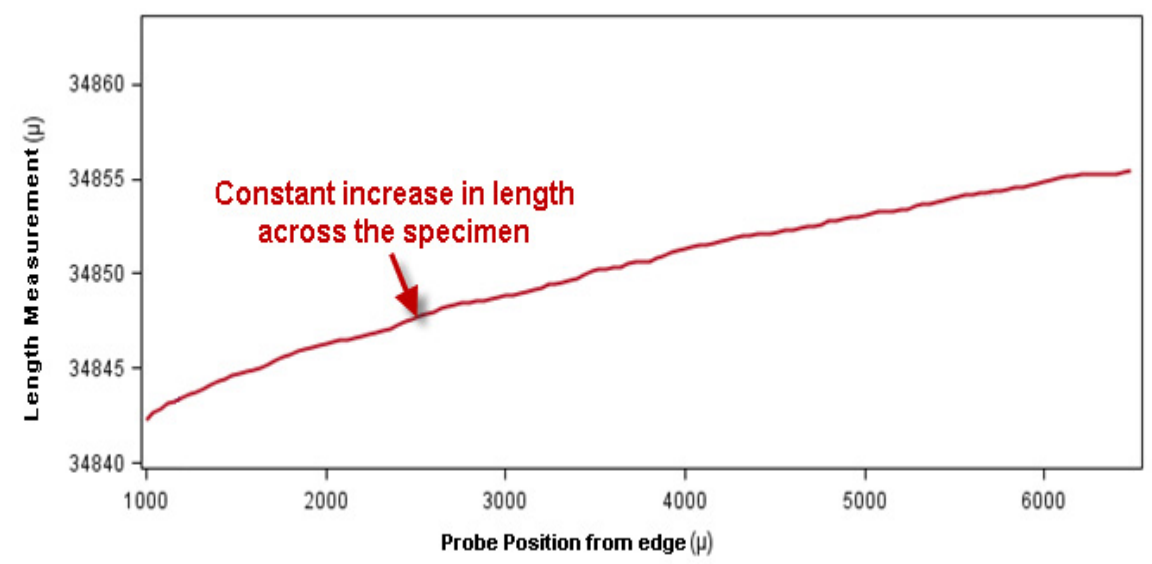

Figure 13: A Typical and Unique Measurement Profile.

Graphical profile summaries from both devices for the four reference specimens are shown below in Figure 15. While the profile and offset differences were not huge, the differences were not consistent. Only one profile out of the four measured during this validation exercise was essentially the same.

- Reference Specimen AR20X-6: Profile is similar, offset is constant.

- Reference Specimen AR20X-16: Profile slightly different, offset is irregular.

- Reference Specimen AR20X-17: Profile is similar, offset is slightly irregular.

- Reference Specimen AR20X-18: Profile slightly different, offset irregular 

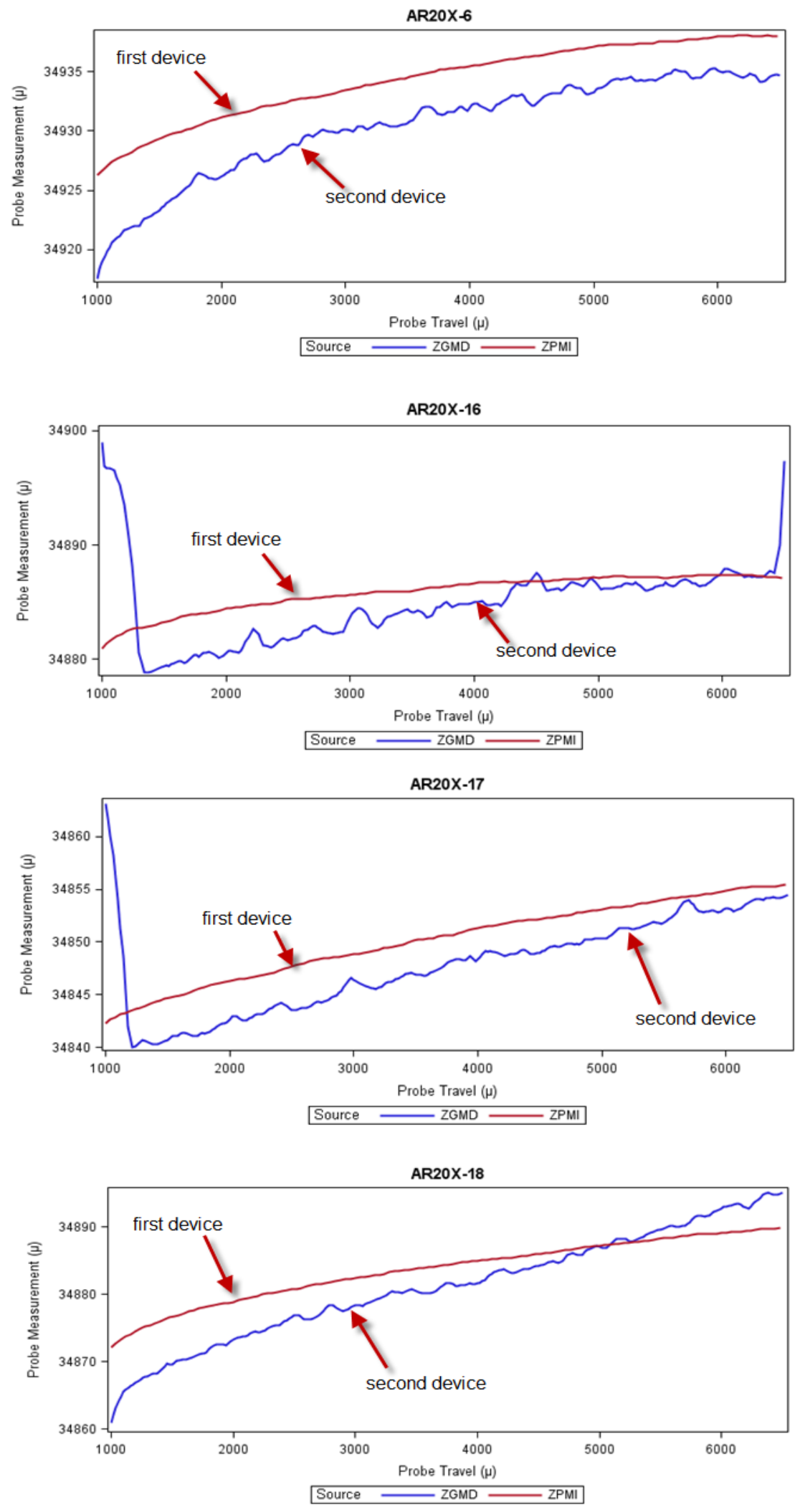

Figure 14: Reference Specimen Profile Comparisons. 
Inspection of the measuring devices revealed the probes are not measuring at the same elevation across the ends of the specimens as shown in Figure 15. The same surface variation that produces a unique profile also means the specimen has measured surfaces that vary in slope and roughness in an unpredictable pattern across the surfaces. The combination of specimen surface variance (non-square specimen ends) and differences in probe elevation results in dissimilar measurements when comparing the original measurement system and the new measurement system. This was observed as the cause of minor differences between original and current measurements
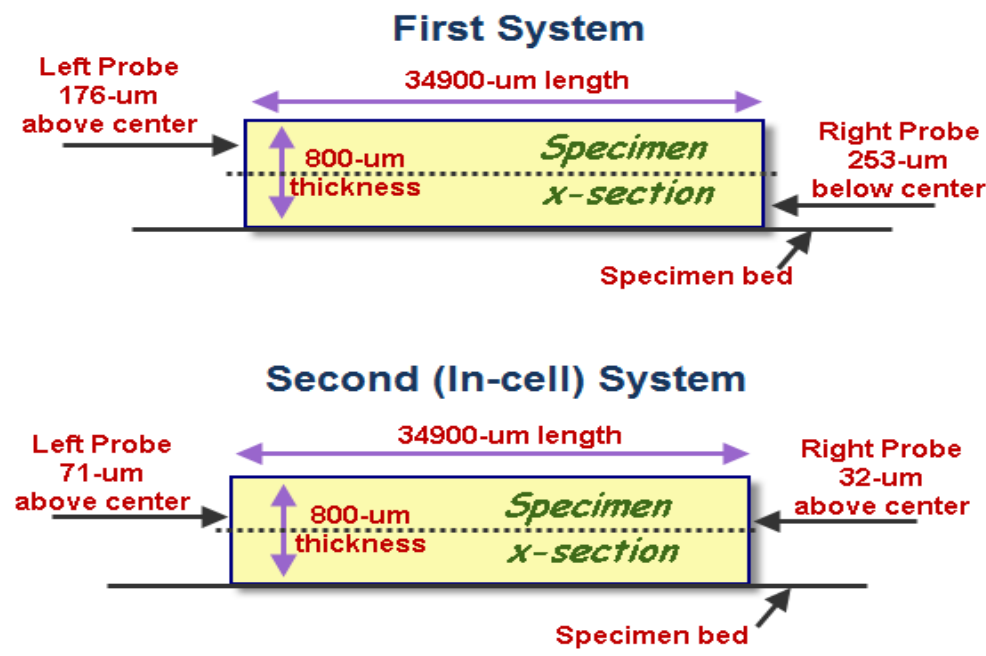

Figure 15: Probe Elevation Differences (not to scale).

\section{Validation Results}

Data and results of the calibration and validation of the second measuring device are included in the appendix, References 3 and 4. INL analysis ECAR-2389 will be released that contains much of this same data and details of calculating the results. Results for the first device are similar and are detailed in INL Plan-3703.

Measurements with QA precision gage blocks were used to initially validate device performance and calibrate the probe zero location on the integral specimen holder block. Hands-on handling was needed to place the precision gage blocks without probe interference where the specimen is normally held and engage probes for start or end measurements. Analysis of measurements between different precision QA gage blocks determined the average measurement error of the device is $-0.025-\mu \mathrm{m}$.

Measuring between QA precision gage blocks and the zero location on the specimen holder starts or ends the probes on a known gage block width and allowed calculation of the unknown zero location width. These measurements established a zero width of 34.0397-mm (1.34015"). Independently measuring this zero location on the integral holding block with a coordinate measuring machine (CMM) resulted in a 34.0379-mm (1.34007") measurement. The 1.8- $\mu \mathrm{m}$ (0.00007') is within the CMM minimum error or $+/-2-\mu \mathrm{m}$. 
Measurements of all four reference specimens with the new measurement device were conducted out-of-cell and two were repeated in-cell. The out-of-cell results revealed that even with the known differences in probe position, the second measuring device performed within the required uncertainty bounds. The maximum average error was $3.637-\mu \mathrm{m}$ for a single specimen and averaged $2.759-\mu \mathrm{m}$ error for all four specimens when compared to the original measurements with the first device. These are both well below the desired 5- $\mu \mathrm{m}$ measurement error threshold. The graphical comparison of these measurements is shown in the previously discussed Figure 14 and a summary table in appendix Reference 5.

Two of the four reference specimens, AR20X-17 and ZR20X-18, were sent in-cell and remeasurement showed the measurements repeated with average errors of $1.601-\mu \mathrm{m}$ and $1.705-$ $\mu \mathrm{m}$. Graphical illustration of these measurements is show in Figure 16 and a summary table in appendix Reference 6 .
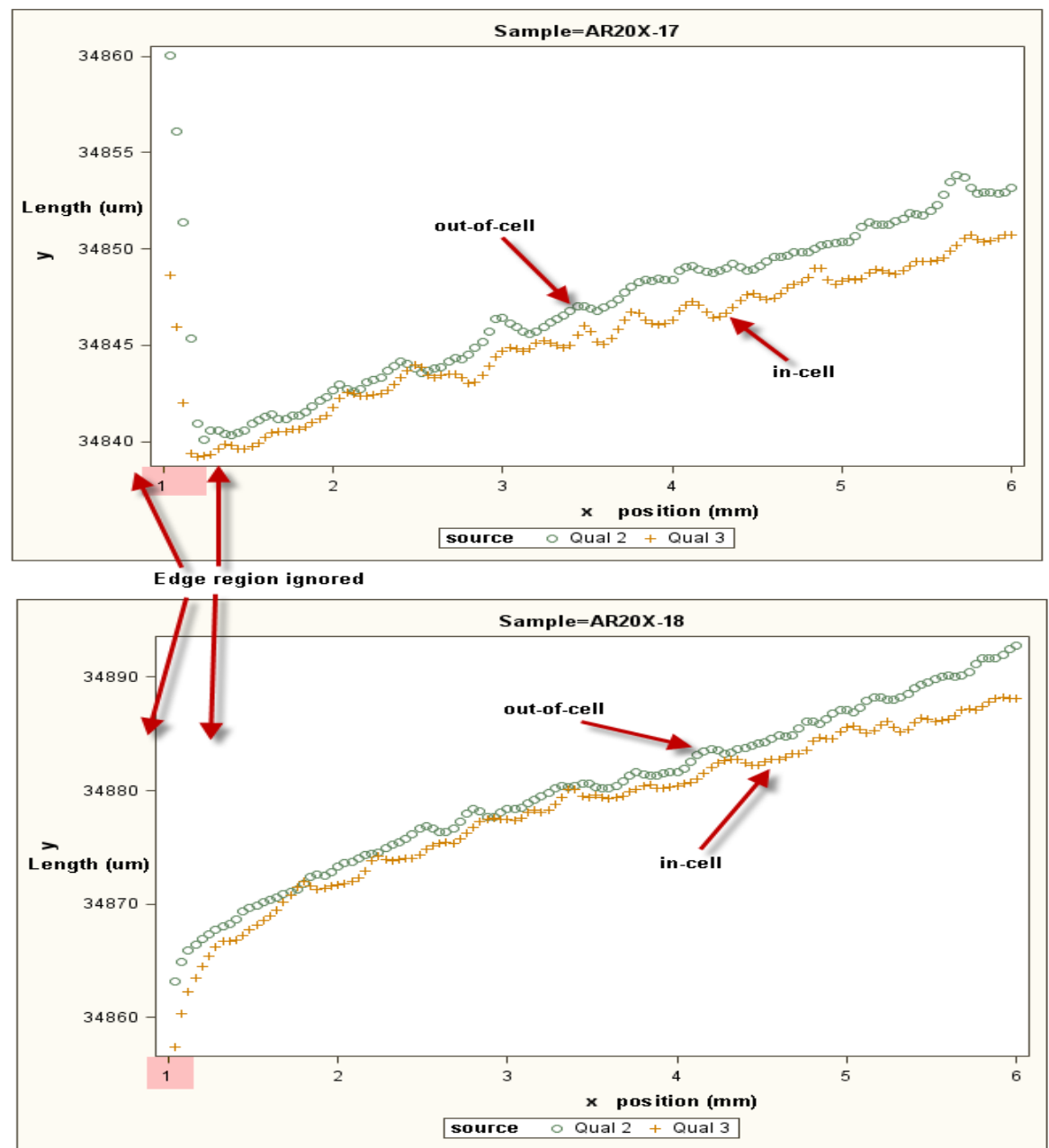

Figure 16: In-cell Verification with Reference Specimens. 


\section{In-cell Measuring Process}

The equipment must be successfully connected, operational checks must be completed, and the measuring device must be moved into the load position. Large tweezes, 8" to 10" long, are used to remove the specimens from their storage containers and perform all handling operations. The specimen identification (ID) is verified and then it is dipped into alcohol to clean surfaces. The specimen is placed on the holding block. The centering slide is then released and spring pressure moves the tapered sides forward to center the specimen. The specimen ID is entered into the software control program and forward motion of the slide is initiated. The initial motion allows spring loaded clamps to secure the specimen while measurements are being taken. The slide moves to the zero position and probes are zeroed. The control software then moves the specimen into measuring position on the leading edge and begins jogged motion across the end surfaces, typically $40 \mu \mathrm{m}$ with each jog, recording the position of each probe. Near the trailing edge of the specimen, the motion is reversed and the process continues taking measurements as the slide returns to the starting position. It takes approximately two-minutes to record over 320 measurements at $40 \mu \mathrm{m}$ spacing forward and back across the specimen ends. At the end of the measuring process the slide position, probe measurements, and temperature data are written to a text file for later retrieval. The slide motion continues back to the loading position. The centering slide and specimen clamps are reset with the final few millimeters of travel. The measured specimen is removed and stored. The process is ready to repeat for another measuring process. The complete remote process averages about eight-minutes to retrieve and measure each specimen.

\section{Summary}

In spite of the uncertainty resulting from the combination of differences in probe measuring elevations and the unpredictability of specimen surface conditions, the ZPMI measurements have met the design requirements as demonstrated by the validation results and the equipment is capable of performing the required measurements. 


\section{Appendix}

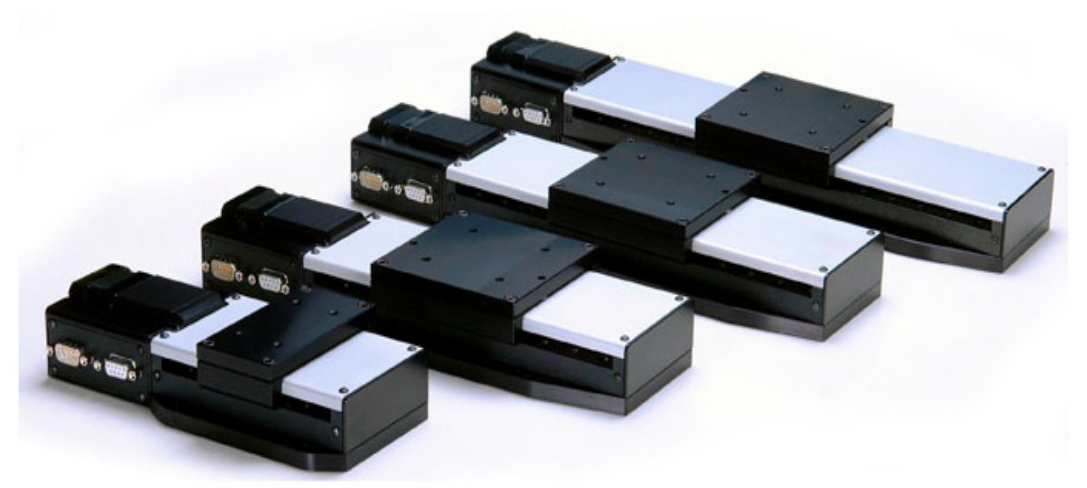

Newmark Systems

NLS4 Series Precision Linear Stage

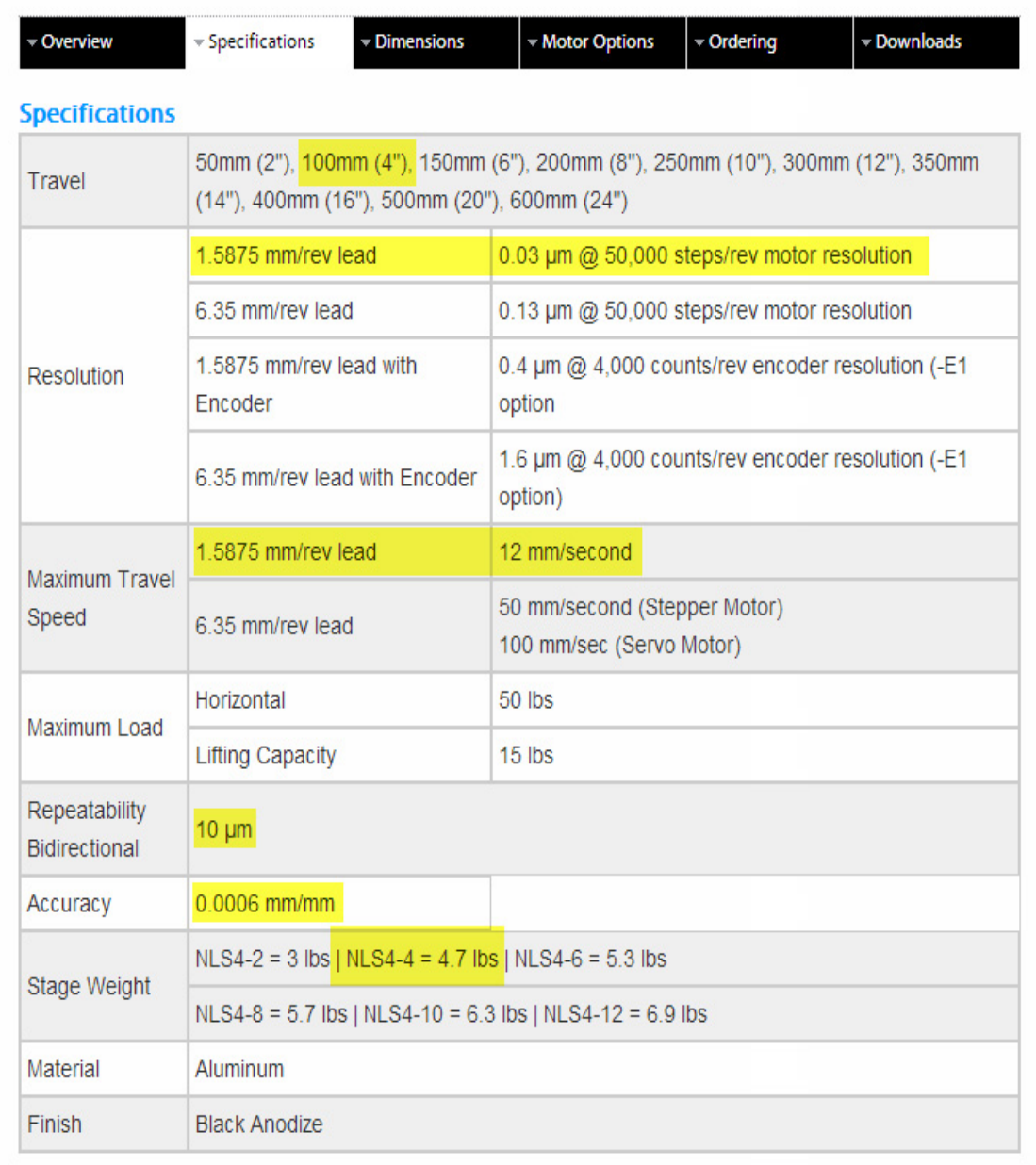

Reference 1: Newmark Linear Positioner Specifications. 


\section{obercaneme}

\section{DG805 вйL DG810 ванға}

High accuracy, compact and slim gauges

Suitable for installation on machines

-Magnetic principle

Excellent resistance to workshop conditions.

Resistant to dust and vibrations.

-Accuracy: $\pm 1 \mu \mathrm{m}$

- Resolution: $0.5 \mu \mathrm{m}$

-Measuring range: $5.2 \mathrm{~mm} / 0.20 "$ and $10 \mathrm{~mm} / 0.39^{\prime \prime}$

-Compact and slim: $8 \mathrm{~mm} / 0.31$ " (outer diameter)

- Low measuring force $4.5 \mathrm{~mm} / 2.93$ " (overall length) (DG805BL)

- Spindle can be

moved vertically with an air pressure device

(DG805BL/810BL)

-Dustproof bellows (standard)

-Easy installation. Flange type gauges also available.
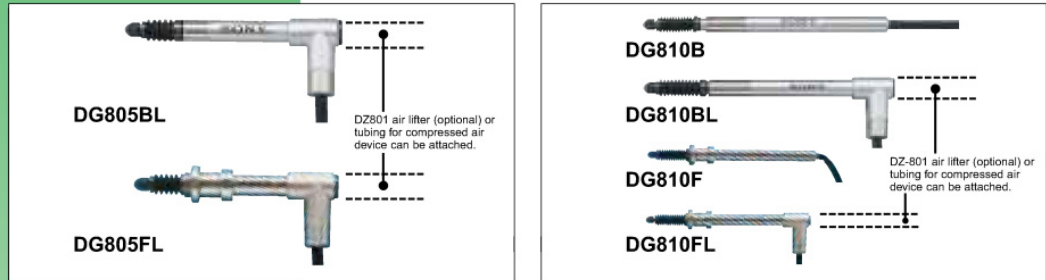

Specifications

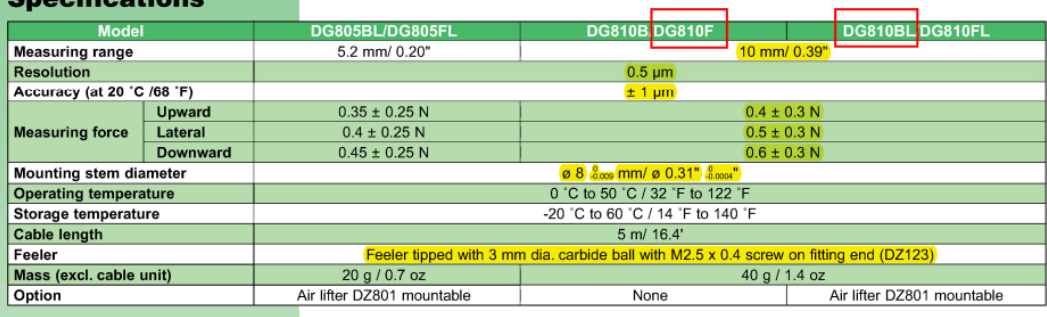

Dimensions

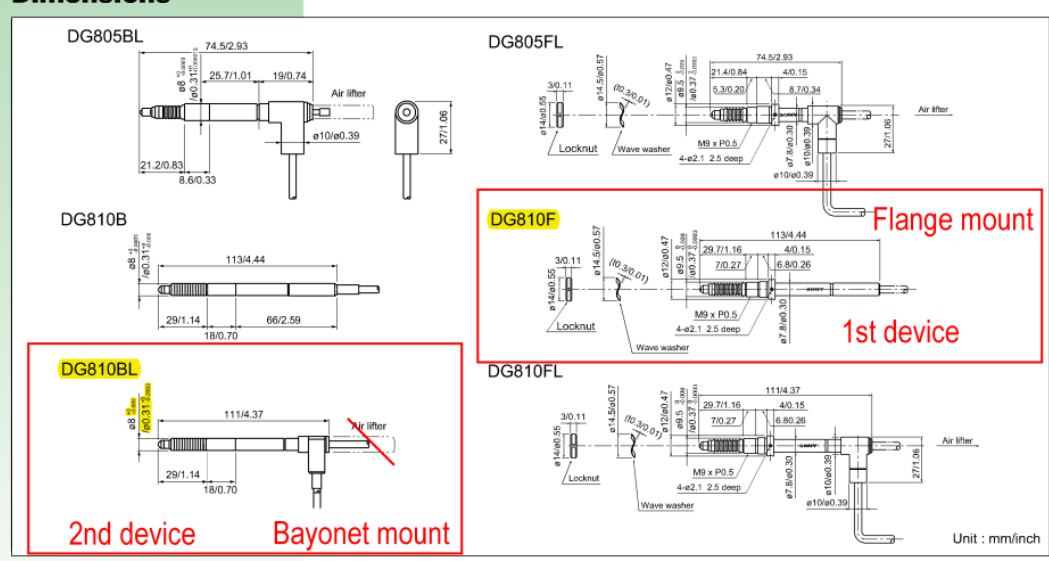

Reference 2: Sony Probe Specifications. 
ZGMD Probe Measure Verification

(New in-cell system)

Precision Gauge Blocks: DoAll Set \#31-R, Serial 5847

Accuracy $+4 / 2$ (0.00000X-in)

Blocks replaced the normally meas ured specimen

Slide was positioned at $92-\mathrm{mm}$ for meas urements

Specimen clamps were not us ed

Data taken 8-7-2013

Avg Error: -0.025 -um Std Dev: 1.95-um

\begin{tabular}{|c|c|c|c|c|c|c|c|}
\hline $\begin{array}{c}\text { Zero } \\
\text { Block } \\
\text { (inches) }\end{array}$ & $\begin{array}{l}\text { Measured } \\
\text { Block } \\
\text { (inches) }\end{array}$ & $\begin{array}{c}\text { Differ- } \\
\text { ential } \\
\text { (inches) }\end{array}$ & $\begin{array}{l}\text { Differ- } \\
\text { ential } \\
(\mathrm{mm})\end{array}$ & $\begin{array}{l}\text { Right } \\
\text { Probe } \\
(\mathrm{mm})\end{array}$ & $\begin{array}{l}\text { Left } \\
\text { Probe } \\
(\mathrm{mm})\end{array}$ & $\begin{array}{l}\text { Probe } \\
\text { Sum } \\
(\mathrm{mm})\end{array}$ & $\begin{array}{l}\text { Error } \\
(\mathrm{mm})\end{array}$ \\
\hline 2.0000 & 1.7000 & -0.3000 & -7.6200 & -4.5030 & -3.1165 & -7.6195 & 0.0005 \\
\hline 2.0000 & 1.7000 & -0.3000 & -7.6200 & -2.4690 & -5.1475 & -7.6165 & 0.0035 \\
\hline 2.0000 & 1.7000 & -0.3000 & -7.6200 & -3.2575 & -4.3635 & -7.6210 & -0.0010 \\
\hline 2.0000 & 1.7000 & -0.3000 & -7.6200 & -2.1860 & -5.4320 & -7.6180 & 0.0020 \\
\hline 2.0000 & 1.7000 & -0.3000 & -7.6200 & -4.4045 & -3.2145 & -7.6190 & 0.0010 \\
\hline 2.0000 & 1.7000 & -0.3000 & -7.6200 & -3.5395 & -4.0780 & -7.6175 & 0.0025 \\
\hline 2.0000 & 1.7000 & -0.3000 & -7.6200 & -5.8690 & -1.7540 & -7.6230 & -0.0030 \\
\hline 2.0000 & 1.7000 & -0.3000 & -7.6200 & -3.6795 & -3.9370 & -7.6165 & 0.0035 \\
\hline 2.0000 & 1.7000 & -0.3000 & -7.6200 & -4.0830 & -3.5350 & -7.6180 & 0.0020 \\
\hline 2.0000 & 1.7000 & -0.3000 & -7.6200 & -3.8460 & -3.7715 & -7.6175 & 0.0025 \\
\hline 2.0000 & 1.7000 & -0.3000 & -7.6200 & -2.8905 & -4.7320 & -7.6225 & -0.0025 \\
\hline 1.7000 & 2.0000 & 0.3000 & 7.6200 & 2.4215 & 5.1965 & 7.6180 & -0.0020 \\
\hline 1.7000 & 2.0000 & 0.3000 & 7.6200 & 3.7610 & 3.8585 & 7.6195 & -0.0005 \\
\hline 1.7000 & 2.0000 & 0.3000 & 7.6200 & 3.6435 & 3.9755 & 7.6190 & -0.0010 \\
\hline 1.7000 & 2.0000 & 0.3000 & 7.6200 & 3.6250 & 3.9950 & 7.6200 & 0.0000 \\
\hline 1.7000 & 2.0000 & 0.3000 & 7.6200 & 3.0100 & 4.6105 & 7.6205 & 0.0005 \\
\hline 1.7000 & 2.0000 & 0.3000 & 7.6200 & 4.0220 & 3.5990 & 7.6210 & 0.0010 \\
\hline 1.7000 & 2.0000 & 0.3000 & 7.6200 & 2.7590 & 4.8625 & 7.6215 & 0.0015 \\
\hline 1.7000 & 2.0000 & 0.3000 & 7.6200 & 3.8630 & 3.7525 & 7.6155 & -0.0045 \\
\hline 1.7000 & 2.0000 & 0.3000 & 7.6200 & 3.9270 & 3.6915 & 7.6185 & -0.0015 \\
\hline 1.4000 & 1.7000 & 0.3000 & 7.6200 & 3.7945 & 3.8260 & 7.6205 & 0.0005 \\
\hline 1.4000 & 1.7000 & 0.3000 & 7.6200 & 4.7395 & 2.8810 & 7.6205 & 0.0005 \\
\hline 1.4000 & 1.7000 & 0.3000 & 7.6200 & 5.1015 & 2.5180 & 7.6195 & -0.0005 \\
\hline 1.4000 & 1.7000 & 0.3000 & 7.6200 & 4.5030 & 3.1150 & 7.6180 & -0.0020 \\
\hline 1.4000 & 1.7000 & 0.3000 & 7.6200 & 5.5245 & 2.0970 & 7.6215 & 0.0015 \\
\hline 1.4000 & 1.7000 & 0.3000 & 7.6200 & 4.7675 & 2.8520 & 7.6195 & -0.0005 \\
\hline 1.4000 & 1.7000 & 0.3000 & 7.6200 & 6.1745 & 1.4480 & 7.6225 & 0.0025 \\
\hline 1.4000 & 1.7000 & 0.3000 & 7.6200 & 1.8485 & 5.7700 & 7.6185 & -0.0015 \\
\hline 1.4000 & 1.7000 & 0.3000 & 7.6200 & 2.9155 & 4.7070 & 7.6225 & 0.0025 \\
\hline 1.4000 & 1.7000 & 0.3000 & 7.6200 & 4.6380 & 2.9820 & 7.6200 & 0.0000 \\
\hline 1.7000 & 1.4000 & -0.3000 & -7.6200 & -3.9765 & -3.6450 & -7.6215 & -0.0015 \\
\hline 1.7000 & 1.4000 & -0.3000 & -7.6200 & -4.7335 & -2.8890 & -7.6225 & -0.0025 \\
\hline 1.7000 & 1.4000 & -0.3000 & -7.6200 & -5.7635 & -1.8540 & -7.6175 & 0.0025 \\
\hline 1.7000 & 1.4000 & -0.3000 & -7.6200 & -5.8155 & -1.8065 & -7.6220 & -0.0020 \\
\hline 1.7000 & 1.4000 & -0.3000 & -7.6200 & -3.8670 & -3.7510 & -7.6180 & 0.0020 \\
\hline 1.7000 & 1.4000 & -0.3000 & -7.6200 & -3.7180 & -3.9040 & -7.6220 & -0.0020 \\
\hline 1.7000 & 1.4000 & -0.3000 & -7.6200 & -2.6435 & -4.9795 & -7.6230 & -0.0030 \\
\hline 1.7000 & 1.4000 & -0.3000 & -7.6200 & -2.8280 & -4.7930 & -7.6210 & -0.0010 \\
\hline 1.7000 & 1.4000 & -0.3000 & -7.6200 & -3.0835 & -4.5350 & -7.6185 & 0.0015 \\
\hline 1.7000 & 1.4000 & -0.3000 & -7.6200 & -3.4970 & -4.1255 & -7.6225 & -0.0025 \\
\hline
\end{tabular}

Reference 3: Precision Gauge Block Validation of Probes. 


\section{ZGMD Zero Measurement (new in-cell system)}

Precision gauge blocks: DoAll Set $\# 81-R$, Serial 5847

Accuracy $+4 /-2$ (0.00000X-in)

Blocks replaced the normally measured specimen

Specimen clamps were not used

Zero position is with the slide at $86.5-\mathrm{mm}$

Precision gauge blocks measured around slide position 92-mm

Measurements were made both to and from a precision gauge block

Zero column indicates probes zeroed on either the holding block (no value) or listed gauge block

Measured column indicates probes measured listed gauge block or the holding block

Data taken between 7-24-2013 and 7-31-2-13

Avg Zero Measure: 34039.7-um Std Dev: 2.3-um

\begin{tabular}{|c|c|c|c|c|c|}
\hline $\begin{array}{c}\text { Zero } \\
\text { Block } \\
\text { (inches) }\end{array}$ & $\begin{array}{l}\text { Measured } \\
\text { Block } \\
\text { (inches) }\end{array}$ & $\begin{array}{l}\text { Right } \\
\text { Probe } \\
(\mathrm{mm})\end{array}$ & $\begin{array}{c}\text { Left } \\
\text { Probe } \\
(\mathrm{mm})\end{array}$ & $\begin{array}{l}\text { Probe } \\
\text { Sum } \\
(\mathrm{mm})\end{array}$ & $\begin{array}{c}\text { Estimated } \\
\text { measuring block } \\
\text { width }(\mathrm{mm})\end{array}$ \\
\hline & 2.0000 & 7.9790 & 8.7775 & 16.7565 & 34.0435 \\
\hline & 2.0000 & 8.6130 & 8.1390 & 16.7520 & 34.048 \\
\hline & 2.0000 & 7.9945 & 8.7595 & 16.7540 & 34.046 \\
\hline & 2.0000 & 9.1195 & 7.6325 & 16.7520 & 34.048 \\
\hline & 2.0000 & 10.0025 & 6.7600 & 16.7625 & 34.0375 \\
\hline & 2.0000 & 9.3570 & 7.4040 & 16.7610 & 34.039 \\
\hline & 2.0000 & 8.5100 & 8.2515 & 16.7615 & 34.0385 \\
\hline & 2.0000 & 8.5290 & 8.2300 & 16.7590 & 34.041 \\
\hline & 2.0000 & 9.4110 & 7.3470 & 16.7580 & 34.042 \\
\hline & 2.0000 & 7.9465 & 8.8130 & 16.7595 & 34.0405 \\
\hline & 2.0000 & 8.5805 & 8.1870 & 16.7675 & 34.0325 \\
\hline & 2.0000 & 8.5100 & 8.2390 & 16.7490 & 34.051 \\
\hline & 2.0000 & 8.4965 & 8.2555 & 16.7520 & 34.048 \\
\hline 2.0000 & & -9.1210 & -7.6390 & -16.7600 & 34.04 \\
\hline 2.0000 & & -9.1215 & -7.6390 & -16.7605 & 34.0395 \\
\hline 2.0000 & & -9.4135 & -7.3455 & -16.7590 & 34.041 \\
\hline \multirow[t]{2}{*}{2.0000} & & -7.5515 & -9.2090 & -16.7605 & 34.0395 \\
\hline & 1.8500 & 6.8045 & 6.1485 & 12.9530 & 34.037 \\
\hline 1.8500 & & -6.5030 & -6.4555 & -12.9585 & 34.0315 \\
\hline \multirow[t]{5}{*}{1.8500} & & -6.8040 & -6.1485 & -12.9525 & 34.0375 \\
\hline & 1.4500 & 1.4125 & 1.3835 & 2.7960 & 34.034 \\
\hline & 1.4500 & 1.4200 & 1.3765 & 2.7965 & 34.0335 \\
\hline & 1.4500 & 1.2450 & 1.5500 & 2.7950 & 34.035 \\
\hline & 1.4500 & 1.1170 & 1.6835 & 2.8005 & 34.0295 \\
\hline
\end{tabular}

\section{Independent Measurement of Zero Reference}

Brown \& Sharpe Coordinate Measuring Machine(CMM): Model 575

Probe tip: TP200

Dimensional uncertainty: $1.9+L / 333 \mu m$

\begin{tabular}{|l|c|c|}
\hline \multicolumn{1}{|c|}{ Description } & Zero Reference & Uncertainty \\
\hline $\begin{array}{l}\text { CMM horizontal measured width at } 86.5 \mathrm{~mm} \text { position on } \\
\text { specimen holding block replicating the probe position } \\
\text { elevations }\end{array}$ & $34037.9 \mu \mathrm{m}$ & $+/-2 \mu \mathrm{m}$ \\
$(1.34007 ")$ & $(+/-0.00008 \mathrm{in})$ \\
\hline
\end{tabular}

Reference 4: Zero Measure Calculation. 


\begin{tabular}{|c|c|c|c|c|}
\hline \multicolumn{5}{|c|}{$\begin{array}{c}\text { Sample }=\text { AR20X-16 } \\
\text { Analysis Variable : Error }\end{array}$} \\
\hline $\mathbf{N}$ & Mean & Std Dev & Minimum & Maximum \\
\hline 113 & 1.8783972 & 1.2682259 & -0.4899650 & 4.1419366 \\
\hline \multicolumn{5}{|c|}{$\begin{array}{c}\text { Sample }=\text { AR20X-17 } \\
\text { Analysis Variable : Error }\end{array}$} \\
\hline $\mathbf{N}$ & Mean & Std Dev & Minimum & Maximum \\
\hline 113 & 2.9690180 & 0.8390163 & 0.4453793 & 4.4138973 \\
\hline \multicolumn{5}{|c|}{$\begin{array}{c}\text { Sample }=\text { AR20X-18 } \\
\text { Analysis Variable : Error }\end{array}$} \\
\hline $\mathbf{N}$ & Mean & Std Dev & Minimum & Maximum \\
\hline 113 & 2.5510582 & 2.6947387 & -3.6808878 & 6.9469448 \\
\hline \multicolumn{5}{|c|}{$\begin{array}{c}\text { Sample=AR20X-6 } \\
\text { Analysis Variable : Error }\end{array}$} \\
\hline $\mathbf{N}$ & Mean & Std Dev & Minimum & Maximum \\
\hline 113 & 3.6371583 & 0.6924792 & 2.4589810 & 5.8716262 \\
\hline \multicolumn{5}{|c|}{$\begin{array}{l}\text { Average for all } 4 \text { specimens } \\
\text { Analysis Variable : Error }\end{array}$} \\
\hline $\mathbf{N}$ & Mean & Std Dev & Minimum & Maximum \\
\hline 452 & 2.7589079 & 1.7047147 & -3.6808878 & 6.9469448 \\
\hline
\end{tabular}

Table summarizes 20 measurements taken with both the first and second devices of each reference specimen. Only 113 points from the central regions were analyzed to avoid problems with corner data. The average mean and standard deviation of the error or difference between the two data sets are reported along with single point minimum and maximum values. The bottom three rows report the average for all data sets combined.

Reference 5: Validation of Second Device to First Device Measurements. 


\begin{tabular}{|l|c|c|c|r|r|}
\hline \multicolumn{7}{|c|}{ Sample=AR20X-17 } \\
\hline Variable & N & Mean & \multicolumn{1}{|c|}{ Std Dev } & Minimum & Maximum \\
\hline Mean_Q2 & 113 & 34847.41 & 3.6415988 & 34840.95 & 34853.85 \\
Mean_Q3 & 113 & 34845.81 & 2.9827583 & 34839.77 & 34850.71 \\
Error & 113 & -1.6012452 & 0.8131032 & -3.6438529 & 0.3061374 \\
\hline \multicolumn{7}{|c|}{ Sample=AR20X-18 } \\
\hline Variable & N & Mean & Std Dev & Minimum & Maximum \\
\hline Mean_Q2 & 113 & 34881.44 & 6.1039593 & 34869.83 & 34892.79 \\
Mean_Q3 & 113 & 34879.74 & 5.4021986 & 34868.16 & 34888.26 \\
Error & 113 & -1.7049073 & 1.0273041 & -4.6563970 & 0.2189529 \\
\hline
\end{tabular}

Table summarizes 20 measurements taken with the second device for the two reference specimens measured both out-of-cell (Q2) and in-cell (Q3).

Reference 6: Validation of In-cell to Out-of-Cell Measurements. 